Seminar Nasional Hasil Penelitian dan Pengabdian Kepada Masyarakat 2021 Pengembangan Ekonomi Bangsa Melalui Inovasi Digital Hasil Penelitian dan Pengabdian Kepada Masyarakat 2021 Jakarta, 21 Oktober 2021

\title{
PROFIL IKLAN SUSU FORMULA SEBAGAI PRODUK PENGGANTI ASI YANG DIMUAT PADA MAJALAH KEDOKTERAN
}

\author{
Michelle Ruth Natalie ${ }^{1}$, Wiyarni Pambudi ${ }^{2}$ \\ ${ }^{1,2,3}$ Program Studi Kedokteran, Fakultas Kedokteran, Universitas Tarumanagara Jakarta \\ Email: michelle.405180019@stu.untar.ac.id, wiyarni@fk.untar.ac.id
}

\begin{abstract}
The rampant marketing of Breastmilk Substitutes products, especially infant formula in various mass media has caused many mothers to stop providing breast milk for their babies. One of the media used to market Breastmilk Substitutes products is medical journals. Marketing of infant formula and other Breastmilk Substitutes products is regulated by regulations that are still applicable until now. The purpose of this study was to determine how the profile of infant formula advertisements as Breastmilk Substitutes product in medical journals, as well as the level of compliance with the applicable regulations. In addition, researcher also wanted to know about the level of knowledge of health workers regarding the regulations governing the marketing of Breastmilk Substitutes products. This study used a descriptive design with a cross-sectional approach and included 24 advertisements for infant formula and 27 health workers. The sampling technique used was simple random sampling and data collection was carried out online from December 2020 to January 2021. The instruments used were a checklist contains the suitability of the infant formula advertisement with the applicable regulations governing it and also a questionnaire. 15 out of 24 advertisements of infant formula (62.50\%) were categorized at the moderate level of conformity, which fulfilled 6 to 8 predetermined criteria. There were 21 out of 27 health workers (77.78\%) who had a sufficient level of knowledge, which fulfilled 2 to 5 of the total 8 questions on the questionnaire. Overall, the conformity level of the infant formula advertisements with the Breastmilk Substitutes regulations is moderate; and the health workers' knowledge about the Breastmilk Substitutes regulations is sufficient.
\end{abstract}

Keywords: Advertisement; Infant formula; Medical journal; Breastmilk Substitutes

\section{ABSTRAK}

Maraknya pemasaran produk Pengganti ASI, khususnya susu formula di berbagai media massa menyebabkan banyak ibu yang tidak lagi memberi ASI kepada bayinya. Salah satu media yang digunakan untuk memasarkan produk Pengganti ASI adalah majalah kedokteran. Pemasaran susu formula beserta produk Pengganti ASI lainnya diatur dalam peraturan-peraturan yang masih berlaku sampai saat ini. Tujuan daripada penelitian ini adalah untuk mengetahui bagaimana profil iklan susu formula sebagai produk Pengganti ASI pada majalah kedokteran, serta tingkat kesesuaiannya dengan ketentuan yang mengatur mengenai pemasaran produk Pengganti ASI. Selain itu peneliti juga ingin mengetahui mengenai tingkat pengetahuan tenaga kesehatan mengenai peraturan yang mengatur tentang pemasaran Pengganti ASI. Penelitian ini menggunakan desain deskriptif dengan pendekatan cross-sectional dan mengikutsertakan 24 iklan susu formula bayi serta 27 tenaga kesehatan. Teknik pengambilan sampel yang digunakan adalah simple random sampling dan seluruh pengambilan data dilakukan secara daring pada bulan Desember 2020 sampai Januari 2021. Instrumen yang digunakan berupa daftar tilik kesesuaian iklan susu formula bayi dengan peraturan yang berlaku beserta kuesioner. Sebanyak 15 dari 24 iklan susu formula bayi (62,5\%) dikategorikan pada tingkat kesesuaian sedang, dimana memenuhi 6 hingga 8 kriteria yang telah ditentukan. Terdapat 21 dari 27 orang tenaga kesehatan $(77,78 \%)$ memiliki tingkat pengetahuan cukup, dimana memenuhi 2 hingga 5 dari total 8 pertanyaan pada kuesioner. Secara keseluruhan, tingkat kesesuaian iklan susu formula bayi dengan ketentuan yang mengatur mengenai pemasarannya adalah sedang; dan tingkat pengetahuan tenaga kesehatan mengenai peraturan pemasaran produk Pengganti ASI adalah cukup.

Kata kunci: Iklan; Susu formula; Majalah kedokteran; Pengganti ASI

\section{PENDAHULUAN}

Berdasarkan dari rekomendasi WHO dan UNICEF, ASI merupakan makanan yang paling ideal serta menyusui adalah proses pemberian yang paling alamiah bagi pertumbuhan dan perkembangan bayi. ${ }^{1,2}$ Pada zaman sekarang ini, banyak dijumpai ibu yang tidak lagi memberikan ASI pada bayinya. Hal ini dapat disebabkan oleh berbagai faktor, salah satunya adalah karena maraknya pemasaran produk Pengganti ASI. ${ }^{3}$ Produk Pengganti ASI yang paling sering dipasarkan adalah susu formula, yang kerap kali juga dipasarkan di berbagai majalah 
Seminar Nasional Hasil Penelitian dan Pengabdian Kepada Masyarakat 2021

Pengembangan Ekonomi Bangsa Melalui Inovasi Digital Hasil Penelitian dan

Pengabdian Kepada Masyarakat

Jakarta, 21 Oktober 2021

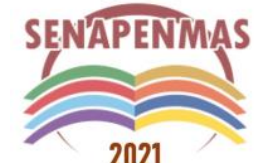

2021

kedokteran. ${ }^{4}$ Pemasaran susu formula beserta produk Pengganti ASI lainnya dalam berbagai media massa sebenarnya telah diatur dalam peraturan yang masih berlaku sampai saat ini. Peraturan Internasional pemasaran produk pengganti ASI dikeluarkan oleh WHA pada tahun 1981. ${ }^{5}$ Indonesia sendiri juga mengadopsi beberapa ketentuan yang tertuang dalam peraturan Internasional tersebut dan ditetapkan dalam peraturan Nasional.

Berdasarkan hasil Riskesdas 2018, proporsi pola pemberian ASI pada bayi usia 0-5 bulan di Indonesia sebanyak 37,3\% ASI eksklusif, 9,3\% ASI parsial, dan 3,3\% ASI predominan. Melihat hasil riset tersebut, dapat dikatakan masih banyak bayi di Indonesia yang belum mendapatkan ASI. ${ }^{6}$ Berdasarkan penelitian yang dilakukan oleh Tal dan Wansink (2014), informasi yang memiliki karakteristik di bidang ilmiah dapat bersifat sangat persuasif bagi penerima informasi tersebut. ${ }^{7}$ Oleh karena itu, penting agar konten pada iklan susu formula dan produk Pengganti ASI lainnya benar-benar diperhatikan kesesuaiannya. Sebuah survei tentang pemasaran, pengiklanan, serta pendistribusian susu formula yang dilakukan oleh Food Safety Authority di Irlandia (2007) menyebutkan bahwa publikasi mengenai susu formula di media publikasi kedokteran kebanyakan tidak memenuhi syarat dan ketentuan yang sudah ditetapkan. ${ }^{8}$

Penelitian Morgan dkk. (2012) melakukan analisis konten iklan susu formula di jurnal kedokteran, dan didapatkan bahwa dari 14 iklan yang mempromosikan susu formula, tidak ada yang kontennya sesuai dengan ketentuan dari WHA. ${ }^{9}$ Oleh sebab itu, peraturan pemasaran produk Pengganti ASI yang dikeluarkan oleh WHA ini tidak hanya ditujukan bagi pemerintah atau produsen susu formula saja, tetapi juga kepada tenaga pelayan kesehatan beserta badannya. Peraturan ini menyebutkan bahwa pemasaran susu formula dan produk Pengganti ASI lainnya hanya boleh dilakukan pada majalah kedokteran, dan harus sesuai dengan ketentuan yang dimuat dalam peraturan yang berlaku. 5,16,17

Mengingat bidang kedokteran atau kesehatan merupakan salah satu bidang yang bersifat sangat persuasif, pemasaran susu formula sebagai produk Pengganti ASI yang paling sering dipromosikan di bidang kedokteran perlu mendapat perhatian dari berbagai pihak, terutama para pelayan kesehatan yang menjadi pembaca dalam majalah-majalah tersebut. ${ }^{10}$ Sampai saat ini, di Indonesia masih belum ada publikasi yang meneliti tentang profil konten iklan Pengganti ASI pada majalah kedokteran. Bermula dari permasalahan tersebut, maka dari itu peneliti ingin melakukan penelitian ini untuk menggambarkan isi publikasi dari iklan susu formula di majalah kedokteran yang beredar di masyarakat serta mengetahui kesesuaian isi publikasi tersebut dengan peraturan yang sudah ditetapkan.

\section{METODE PENELITIAN}

Penelitian ini menggunakan desain deskriptif dengan pendekatan potong-lintang. Penelitian ini dilakukan dengan mengamati iklan susu formula bayi pada majalah kedokteran dan mengukur pengetahuan tenaga kesehatan mengenai peraturan yang mengatur tentang pemasaran susu formula dan secara daring. Waktu penelitian dilaksanakan pada bulan Desember 2020 sampai dengan Januari 2021.

Populasi target pada penelitian ini meliputi iklan susu formula bayi pada majalah kedokteran dan tenaga kesehatan yang bertugas di wilayah Jakarta Barat. Sedangkan populasi yang dapat dijangkau yang merupakan sampel dari penelitian ini adalah iklan susu formula bayi pada majalah kedokteran dengan tahun terbit 2020 dan tenaga kesehatan yang bertugas di Fakultas Kedokteran Universitas Tarumanagara. Kriteria inklusi pada penelitian ini adalah iklan susu formula bayi pada majalah kedokteran yang dapat diakses dan terbit pada tahun 2020 dan tenaga kesehatan yang bertugas di Fakultas Kedokteran Universitas Tarumanagara yang bersedia untuk menjadi responden penelitian. Kriteria eksklusi adalah data dari respon kuesioner yang kurang atau tidak diisi dengan lengkap. 
Penghitungan besar sampel pada penelitian ini menggunakan rumus besar sampel untuk penelitian observasional potong-lintang deskriptif pada populasi infinit, dan didapatkan untuk besar sampel iklan susu formula bayi ${ }^{18}$ pada majalah kedokteran sebanyak 24 sampel dan besar sampel tenaga kesehatan yang bertugas di Fakultas Kedokteran Universitas Tarumanagara sebanyak 24 responden. Seluruh pengambilan sampel dilakukan dengan menggunakan metode simple random sampling.

Pengumpulan data untuk sampel iklan susu formula bayi diambil dari 4 nama majalah kedokteran dengan berbagai edisi terbit. Setelah itu, peneliti membuat daftar tilik kesesuaian iklan susu formula bayi dengan peraturan yang mengatur mengenai pemasaran produk Pengganti ASI. Sebelumnya, peneliti menentukan beberapa poin yang akan menjadi aspek yang diamati dari sampel iklan susu formula bayi, bertolak dari tinjauan pustaka ${ }^{5,12-14,22}$. Setelah daftar tilik rampung, peneliti mengamati dan menilai kesesuaian konten iklan susu formula bayi dengan daftar tilik tersebut, dan kemudian dilakukan scoring pada tiap iklan yang telah diamati kesesuaiannya. Hasil scoring dipetakan sesuai dengan Panduan Kategorisasi 3 Kategori menurut Azwar (2012) ${ }^{20}$, sehingga didapatkan hasil tingkat kesesuaian iklan susu formula bayi dalam 3 kategori: Rendah, Sedang, dan Tinggi.

Sedangkan pada pengumpulan data untuk responden tenaga kesehatan dilakukan pengambilan data dari kuesioner. Didapatkan karakteristik responden yang meliputi jenis kelamin, usia, pendidikan terakhir, bidang yang digeluti/spesialisasi, serta lama pengalaman kerja sebagai dokter. Selain itu, untuk menilai pengetahuan responden terhadap peraturan pemasaran susu formula dan produk Pengganti ASI lainnya, peneliti menentukan beberapa poin yang bertolak dari tinjauan pustaka ${ }^{5,12-14,22}$ dan dikonversi menjadi 8 buah pertanyaan yang dimasukkan dalam kuesioner. Setelah itu, peneliti mengamati respon dari kuesioner yang telah diisi seara daring oleh para responden dan dilakukan scoring pada tiap respon tersebut. Hasil scoring dipetakan dipetakan sesuai dengan Panduan Kategorisasi 3 Kategori menurut Azwar (2012) ${ }^{20}$, sehingga didapatkan hasil tingkat pengetahuan tenaga kesehatan dalam 3 kategori: Kurang, Cukup, dan Baik.

Analisis data dilakukan dengan menggunakan program Microsoft Excel. Hasil penelitian disajikan dalam bentuk tabel, diagram, dan narasi.

\section{HASIL DAN PEMBAHASAN}

Penelitian ini mengikutsertakan 24 iklan susu formula bayi yang sesuai dengan kriteria inklusi dan dipilih melalui teknik pengambilan sampel simple random sampling. Terdapat 4 nama majalah kedokteran dengan berbagai edisi yang peneliti gunakan untuk mengumpulkan sampel iklan susu formula bayi. Keempat nama majalah kedokteran tersebut antara lain: Buletin IDAI; Sari Pediatri; Paediatrica Indonesiana; dan Journal Of Pediatrics, Obstetrics And Gynaecology.

Berdasarkan hasil pengolahan data, data yang didapatkan untuk diolah lebih lanjut yaitu sebanyak 24 sampel yang terdiri dari iklan 9 merk produk susu formula bayi yang dimuat dalam keempat majalah kedokteran tersebut. Karakteristik iklan susu formula bayi yang dimuat pada keempat majalah kedokteran tersebut tertera pada Tabel 1. Peneliti mendapatkan bahwa terdapat pola kemunculan iklan yang mirip pada keempat majalah kedokteran tersebut; seperti contohnya pada majalah Buletin IDAI, pada nomor edisi genap (No. 128, 130, dan 132) iklan susu formula bayi yang dimuat berjumlah 12 dari 24 iklan dan pada nomor edisi ganjil (129 dan 131) iklan susu formula yang dimuat yaitu sebanyak 15 dari 24 iklan. Selain jumlah kemunculan iklan yang berpola, yang menarik adalah merk iklan susu formula yang muncul pun juga sama, bahkan iklan yang tampil pun ada yang benar2 sama persis, dan ada juga beberapa yang iklannya sudah diperbaharui. 
Tabel 1. Karakteristik iklan susu formula bayi

Karakteristik

\begin{tabular}{l}
\hline Merk Susu Formula \\
Bebelac \\
BMT Morinaga \\
Enfamil \\
Friso \\
Lactogen \\
Nutriamigen \\
Nutribaby \\
S26 Procal Gold \\
SGM \\
Nama Majalah Kedokteran \\
Buletin IDAI
\end{tabular}

Sari Pediatri

Paediatrica Indonesiana

Journal Of Pediatrics, Obstetrics And Gynaecology

Kemunculan Iklan Susu Formula Bayi $(\mathrm{n}=24)$

\section{Edisi}

No. 128 Feb XL 2020

No. 129 April XL 2020

No. 130 Juni XL 2020

No. 131 Agst XL 2020

No. 132 Okt XL 2020

Vol. 21 No. 5 Feb 2020

Vol. 21 No. 6 April 2020

Vol. 22 No. 1 Juni 2020

Vol. 22 No. 2 Agst 2020

Vol. 60 No. 1 Jan 2020

Vol. 60 No. 2 Mar 2020

Vol. 60 No. 3 Mei 2020

Vol. 60 No. 4 Juli 2020

Vol. 60 No. 5 Sept 2020

Vol. 11 No. 3 Mei-Jun 2020

Vol. 11 No. 4 Jul-Agst 2020

Vol. 11 No. 5 Sept-Okt 2020
$1(4,17 \%)$

$5(20,83 \%)$

$4(16,67 \%)$

$1(4,17 \%)$

$1(4,17 \%)$

$1(4,17 \%)$

$4(16,67 \%)$

$2(8,33 \%)$

$5(20,83 \%)$

$12(50,00 \%)$

$15(62,50 \%)$

$12(50,00 \%)$

$15(62,50 \%)$

$12(50,00 \%)$

$15(62,50 \%)$

$20(83,33 \%)$

$15(62,50 \%)$

$20(83,33 \%)$

$12(50,00 \%)$

$11(45,83 \%)$

$12(50,00 \%)$

$11(45,83 \%)$

$12(50,00 \%)$

$14(58,33 \%)$

$14(58,33 \%)$

$14(58,33 \%)$

Setelah mengetahui karakteristik dari iklan susu formula bayi yang dimuat pada keempat majalah kedokteran tersebut, peneliti melakukan analisis konten pada 24 sampel iklan susu formula bayi dengan bertolak dari 10 poin ketentuan yang telah ditetapkan seperti yang sudah dijelaskan sebelumnya, sehingga didapatkan profil kesesuaian iklan susu formula bayi dapat dilihat pada Tabel 2 .

Tabel ini memuat daftar tilik kesesuaian iklan susu formula dengan ketentuan yang berlaku, dimana memuat 10 aspek yang menjadi syarat yang harus dipenuhi oleh iklan susu formula bayi yang ingin dipublikasikan pada majalah kedokteran. Hal yang menarik dari sini adalah aspek/poin yang ke-5, yang syaratnya yaitu "Tidak mencantumkan klaim bahwa produk memiliki manfaat bagi tumbuh kembang dan kesehatan bayi". Didapatkan dari hasil penelitian ini, dari 24 sampel iklan, hanya satu diantaranya yang mematuhi persyaratan ini. Hal ini didukung oleh penelitian Berry dkk. (2012) yang menyatakan hanya 32,90\% yang mematuhi persyaratan ini.

Menurut peneliti, hal ini dapat disebabkan oleh jika misalnya pihak produsen/distributor susu formula tidak mencantumkan klaim bahwa produknya memiliki manfaat bagi kesehatan bayi, para ibu atau konsumen tidak akan tertarik untuk membeli produk dari mereka. Oleh karena itu, tingkat kepatuhan pada poin ini sangat rendah.

Dapat dilihat juga pada aspek yang ke-7 dan ke-8, yaitu "Tidak memasukkan informasi mengenai potongan harga, sayembara berhadiah, dll" dan "Tidak mencantumkan keterangan bahwa produk tersebut adalah Pengganti ASI"; dimana seluruh iklan susu formula bayi (24 dari 24) telah mematuhi kedua aspek persyaratan ini dan hal ini merupakan hal yang baik dan dapat dijadikan pedoman bagi para produsen atau distributor lainnya. 


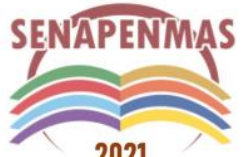

2021

Seminar Nasional Hasil Penelitian dan Pengabdian Kepada Masyarakat 2021

Pengembangan Ekonomi Bangsa Melalui Inovasi Digital Hasil Penelitian dan Pengabdian Kepada Masyarakat Jakarta, 21 Oktober 2021

Selain itu, berdasarkan tinjauan pustaka dari penelitian ini, peneliti menyimpulkan bahwa terdapat 10 aspek yang dijadikan ketentuan untuk diikuti oleh media periklanan susu formula bayi. Sedangkan pada penelitian Morgan dkk. (2012) hanya menetapkan enam aspek sebagai ketentuan yang harus diikuti oleh media periklanan susu formula bayi; dimana dari 10 aspek yang peneliti simpulkan, Morgan dkk. (2012) tidak memasukkan aspek yang pertama, kelima, ketujuh, kedelapan, dan yang terakhir di dalam penelitiannya. Tetapi Morgan dkk. (2012) menetapkan dua aspek yang tidak peneliti masukkan dalam penelitian ini, yaitu mengenai kemiripan antara penggunaan produk Pengganti ASI dengan ASI serta mengenai kalimat persuasif pada iklan susu formula bayi. ${ }^{9}$

Tabel 2. Profil kesesuaian iklan susu formula bayi

\begin{tabular}{|c|c|}
\hline Ketentuan Iklan Susu Formula Bayi ${ }^{5,12-14,22}$ & Jumlah Iklan Susu Formula Bayi $(\mathrm{n}=24)$ \\
\hline $\begin{array}{ll}\text { - } & \begin{array}{l}\text { Mencantumkan tulisan "Susu Formula } \\
\text { peruntukan produk (usia, kondisi bayi, dll.) }\end{array}\end{array}$ & $17(70,83 \%)$ \\
\hline $\begin{array}{l}\text { - Tidak memasukkan foto bayi atau ibu (foto riil maupun } \\
\text { ilustrasi) }\end{array}$ & $13(54,17 \%)$ \\
\hline $\begin{array}{l}\text { - Mencantumkan indikasi medis pemberian susu formula } \\
\text { bayi }\end{array}$ & $11(45,83 \%)$ \\
\hline $\begin{array}{l}\text { Tidak mencantumkan klaim bahwa produk memiliki } \\
\text { kandungan nutrisi yang unggul atau superior daripada } \\
\text { ASI }\end{array}$ & $21(87,50 \%)$ \\
\hline $\begin{array}{l}\text { Tidak mencantumkan klaim bahwa produk memiliki } \\
\text { manfaat bagi tumbuh kembang dan kesehatan bayi }\end{array}$ & $1(4,17 \%)$ \\
\hline $\begin{array}{l}\text { Memasukkan data hasil riset mengenai keunggulan } \\
\text { produk }\end{array}$ & $18(75,00 \%)$ \\
\hline $\begin{array}{l}\text { Tidak memasukkan informasi mengenai potongan harga, } \\
\text { sayembara berhadiah, dll. }\end{array}$ & $24(100,00 \%)$ \\
\hline $\begin{array}{l}\text { - Tidak mencantumkan keterangan bahwa produk tersebut } \\
\text { adalah Pengganti ASI }\end{array}$ & $24(100,00 \%)$ \\
\hline $\begin{array}{l}\text { Mencantumkan keterangan bahwa ASI merupakan } \\
\text { makanan yang terbaik untuk bayi }\end{array}$ & $16(66,67 \%)$ \\
\hline $\begin{array}{l}\text { Tidak memasukkan gambar alat yang digunakan untuk } \\
\text { memberi makanan Pengganti ASI (dot, botol susu, dll.) }\end{array}$ & $23(95,83 \%)$ \\
\hline
\end{tabular}

Peneliti kemudian melakukan pengelompokan terhadap iklan susu formula bayi tersebut untuk mengetahui tingkat kesesuaiannya dengan ketentuan yang telah ditetapkan. Peneliti mengelompokkan tingkat kesesuaian iklan susu formula bayi dengan ketentuan yang berlaku menjadi tiga kategori, yakni Rendah, Sedang, dan Tinggi. Didapatkan dari hasil penelitian bahwa tingkat kesesuaian iklan susu formula bayi terhadap ketentuan yang berlaku yakni iklan dengan tingkat kesesuaian rendah sebanyak empat iklan (16,67\%), iklan dengan tingkat kesesuaian sedang sebanyak 15 iklan $(62,5 \%)$, dan iklan dengan tingkat kesesuaian tinggi sebanyak lima iklan $(20,83 \%)$. Diagram tingkat kesesuaian iklan susu formula bayi terhadap ketentuan yang berlaku tertera pada Gambar 1 .

Menurut hasil penelitian ini, terdapat empat iklan (16,67\%) yang tingkat kesesuaiannya rendah, sebanyak 15 iklan $(62,5 \%)$ dengan tingkat kesesuaian sedang, dan sebanyak lima iklan $(20,83 \%)$ memiliki tingkat kesesuaian tinggi. Hasil penelitian ini kurang sesuai dengan penelitian Morgan dkk. (2012) yang menyatakan bahwa secara keseluruhan tingkat kesesuaian iklan susu formula bayi dengan ketentuan yang berlaku masih rendah. ${ }^{9}$ Perbedaan antara kedua hasil penelitian dapat disebabkan oleh berbagai faktor; seperti faktor subjektivitas penilaian konten iklan susu formula yang dipengaruhi oleh perbedaan tafsiran atau persepsi terhadap iklan yang dianalisis. Selain itu, Morgan dkk. (2012) melaksanakan penelitiannya di Inggris; sehingga terdapat 
Seminar Nasional Hasil Penelitian dan Pengabdian Kepada Masyarakat 2021

Pengembangan Ekonomi Bangsa Melalui Inovasi Digital Hasil Penelitian dan

Pengabdian Kepada Masyarakat

Jakarta, 21 Oktober 2021

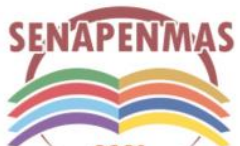

2021

perbedaan kebudayaan, cara pandang, dan hal-hal lainnya antara peneliti dengan Morgan dkk. yang juga mempengaruhi hasil penelitian.

Sebagai upaya untuk menurunkan tingkat subjektivitas penilaian tingkat kesesuaian iklan susu formula bayi dengan ketentuan yang berlaku, peneliti berharap bagi peneliti-peneliti berikutnya yang akan meneliti penelitian dengan topik serupa dapat melakukan penilaian tingkat kesesuaian iklan susu formula bayi dengan beberapa orang penelaah supaya didapatkan hasil penilaian yang lebih objektif.

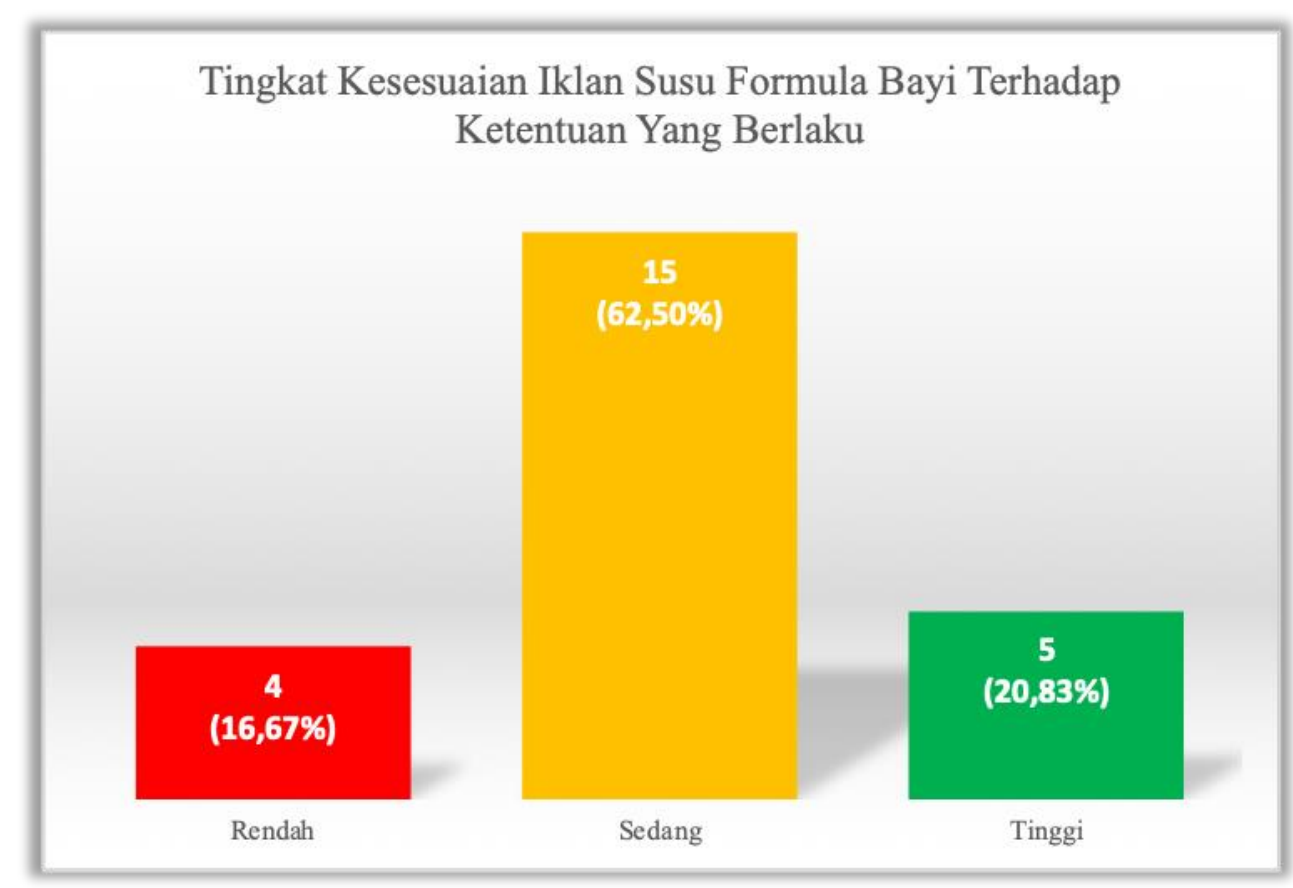

Gambar 1. Tingkat kesesuaian iklan susu formula bayi

Selain itu, penelitian ini juga mengikutsertakan 27 orang tenaga kesehatan yang bertugas di Fakultas Kedokteran Universitas Tarumanagara. Karakteristik dari responden yang telah berpartisipasi dalam penelitian ini dapat dilihat pada Tabel 3. Hasil pengolahan data tenaga kesehatan menunjukkan bahwa sebagian besar dari tenaga kesehatan yang menjadi responden sebagian besar berjenis kelamin perempuan, yaitu sebanyak 19 orang (70,37\%) sedangkan tenaga kesehatan yang berjenis kelamin laki-laki berjumlah delapan orang $(29,63 \%)$.

Setelah mengetahui karakteristik dari tenaga kesehatan yang menjadi responden dalam penelitian ini, peneliti melakukan analisis pengetahuan para tenaga kesehatan mengenai ketentuan yang mengatur Pengganti ASI sehingga didapatkan profil pengetahuan tenaga kesehatan yang dapat dilihat pada Tabel 4. Tabel ini memuat daftar pertanyaan dari kuesioner yang disebarkan kepada para tenaga kesehatan.

Terdapat lima pertanyaan yang ditanyakan dan akan digunakan sebagai tolak pengukuran tingkat pengetahuan tenaga kesehatan. Sebanyak 19 orang $(70,37 \%)$ di antara para tenaga kesehatan tersebut pernah melihat iklan susu formula bayi dimuat pada majalah kedokteran, sedangkan delapan orang $(29,63 \%)$ lainnya belum pernah. 
Tabel 3. Karakteristik responden

\begin{tabular}{lcc}
\hline Karakteristik & $\begin{array}{c}\text { Jumlah } \\
(\mathrm{n}=27)\end{array}$ & $\begin{array}{c}\text { Persentase } \\
(\%)\end{array}$ \\
\hline Jenis Kelamin & 8 & $29,63 \%$ \\
Laki-laki & 19 & $70,37 \%$ \\
Perempuan & & \\
Usia (tahun) & 14 & $51,85 \%$ \\
$30-39$ & 8 & $29,63 \%$ \\
$40-49$ & 3 & $11,11 \%$ \\
50-59 & 2 & $7,41 \%$ \\
Z60 & & \\
Pendidikan Terakhir & 25 & $92,59 \%$ \\
S2/sederajat & 2 & $7,41 \%$ \\
S3/sederajat & & \\
Bidang yang Digeluti & 12 & $44,44 \%$ \\
Preklinis/lmu Kedokteran Dasar & 15 & $55,56 \%$ \\
Klinis/Spesialisasi & & $3,70 \%$ \\
Lama Pengalaman Kerja (tahun) & 1 & $40,74 \%$ \\
$<5$ & 11 & $18,52 \%$ \\
$5-9$ & 5 & $22,22 \%$ \\
$10-14$ & 6 & $14,81 \%$ \\
$15-19$ & 4 & \\
—20 & & \\
\hline
\end{tabular}

Hal yang menarik dari hasil penelitian ini adalah pada pertanyaan nomor lima yaitu apakah tenaga kesehatan yang mengisi kuesioner tersebut telah mengetahui susu formula bayi serta produk Pengganti ASI lainnya hanya boleh diiklankan pada media cetak khusus tentang kesehatan/kedokteran; dan dari hasil penelitian ini, hanya lima dari 27 orang responden yang mengetahui mengenai hal tersebut. Hal ini juga didukung oleh penelitian Berry dkk. (2010) yang menyatakan banyak pihak tenaga kesehatan belum mengetahui mengenai hal ini. Padahal, menurut peneliti poin ini merupakan poin yang sangat penting untuk diketahui oleh para tenaga kesehatan, dalam mengupayakan kegiatan pemberian ASI eksklusif.

Tabel 4. Profil pengetahuan tenaga kesehatan

\begin{tabular}{ll}
\hline Pengetahuan Tenaga Kesehatan $5,12-14,22$ & $\begin{array}{c}\text { Jumlah Tenaga Kesehatan } \\
(\mathrm{n}=27)\end{array}$ \\
\hline - $\quad \begin{array}{c}\text { Pernah melihat iklan susu formula bayi dimuat pada majalah kedokteran } \\
\text { - } \quad \begin{array}{l}\text { Mengetahui adanya kebijakan Internasional yang mengatur pemasaran } \\
\text { produk Pengganti ASI }\end{array}\end{array}$ & $15(55,56 \%)$ \\
- $\begin{array}{l}\text { Mengetahui adanya kebijakan Nasional yang mengatur pemasaran produk } \\
\text { Pengganti ASI }\end{array}$ & $17(62,96 \%)$ \\
- Mengetahui tujuan ditetapkannya kebijakan yang mengatur pemasaran \\
$\begin{array}{l}\text { produk Pengganti ASI } \\
\text { Mengetahui susu formula bayi serta produk Pengganti ASI lainnya hanya } \\
\text { boleh diiklankan pada media cetak khusus tentang kesehatan/kedokteran }\end{array}$
\end{tabular}

Peneliti kemudian melakukan penilaian untuk melihat bagaimana tingkat pengetahuan para tenaga kesehatan tersebut terhadap ketentuan yang mengatur mengenai Pengganti ASI. Peneliti mengelompokkan tingkat pengetahuannya menjadi tiga kategori, yakni Kurang, Cukup, dan Baik. Didapatkan dari hasil penelitian bahwa tingkat pengetahuan tenaga kesehatan terhadap peraturan yang mengatur mengenai Pengganti ASI dengan tingkat pengetahuan kurang sebanyak 4 orang $(14,81 \%)$, tenaga kesehatan dengan tingkat pengetahuan cukup sebanyak 21 orang 
(77,78\%), serta tenaga kesehatan dengan tingkat pengetahuan baik sebanyak dua orang $(7,41 \%)$. Tingkat pengetahuan tenaga kesehatan terhadap ketentuan yang mengatur tentang pemasaran produk Pengganti ASI tertera pada Gambar 2.

Hasil yang didapatkan pada penelitian ini tidak terlalu sesuai dengan penelitian HernándezCordero dkk. (2019) yang menyatakan bahwa hampir 60,00\% dari tenaga kesehatan yang terlibat dalam penelitiannya masih kurang pengetahuan mengenai peraturan yang mengatur mengenai pemasaran Pengganti ASI. ${ }^{19}$

Perbedaan tingkat pengetahuan pada tenaga kesehatan yang ikut serta dalam penelitian ini dapat disebabkan oleh beberapa hal; misalnya seperti bidang yang digeluti. Pada tenaga kesehatan yang menggeluti bidang pediatri, mungkin akan memiliki tingkat pengetahuan yang lebih tinggi daripada yang menggeluti bidang lainnya. Selain itu lama pengalaman kerja, jumlah dan atau jenis majalah kedokteran yang dibaca juga dapat mempengaruhi hasil penelitian.

Peneliti berharap peneliti-peneliti selanjutnya yang akan meneliti penelitian dengan topik serupa dapat melakukan wawancara pada responden tenaga kesehatan agar dapat memperoleh tingkat pengetahuan yang lebih mendalam. Selain itu, sebagai upaya untuk meningkatkan pengetahuan para tenaga kesehatan di Indonesia mengenai peraturan pemasaran produk Pengganti ASI, peneliti berharap ke depannya sosialisasi terkait dengan hal tersebut dapat ditingkatkan lagi.

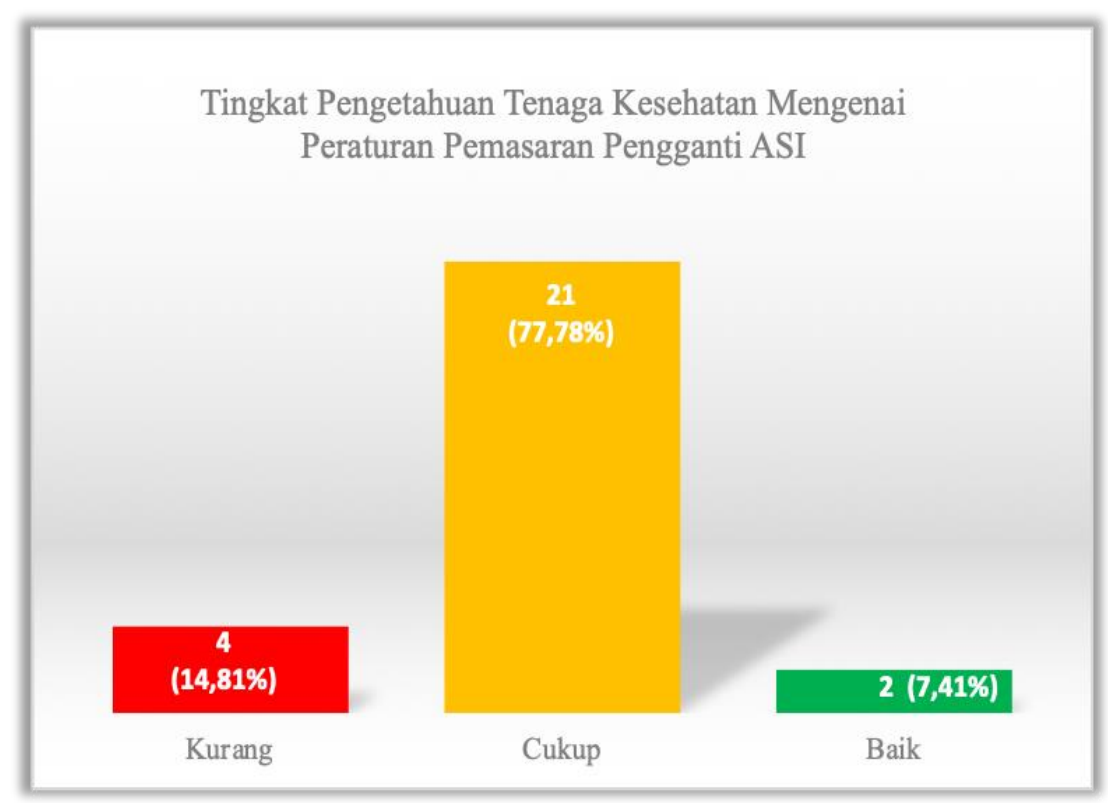

Gambar 2. Tingkat pengetahuan tenaga kesehatan

\section{KESIMPULAN DAN SARAN}

Berdasarkan dari hasil penelitian ini, tingkat kesesuaian iklan susu formula bayi dengan ketentuan yang berlaku adalah sedang dan tingkat pengetahuan tenaga kesehatan yang bertugas di Universitas Tarumanagara terhadap ketentuan yang mengatur mengenai pemasaran produk Pengganti ASI adalah cukup.

Peneliti berharap ke depannya sosialisasi mengenai ketentuan yang mengatur mengenai pemasaran produk Pengganti ASI dapat lebih ditingkatkan lagi guna mendukung kegiatan pemberian ASI eksklusif. 


\section{REFERENSI}

Albab, FU. (2013). Hubungan promosi susu formula dengan pengambilan keputusan keluarga dalam pemberian ASI eksklusif di wilayah kerja puskesmas Arjasa Kabupaten Jember. Jurnal Universitas Jember, 29-37. Available from: https://docplayer.info/31758873-Albabet-al-hubungan-promosi-susu-formula-dengan-pengambilan-keputusan-keluarga.html

Azwar, S. (2012). Metode Penelitian. Pustaka Belajar, Yogyakarta.

Basch, C., Shaffer, E., Hammond, R. \& Rajan, S. (2013). Prevalence of infant formula advertisements in parenting magazines over a 5-year span. Journal of Pediatric Nursing, 28(6): e28-32. Available from: https://pubmed.ncbi.nlm.nih.gov/23906772/Durako, SJ., Thompson, M., Diallo, MS. \& Aronson, KE. (2016). In-country assessments of BMS companies' compliance with the International Code of Marketing of Breast-milk Subtitutes (Final Indonesia Report). Westat, Maryland.

Berry, NJ., Jones, SC. \& Iverson, D. (2012). Toddler Milk Advertising in Australia: Infant Formula Advertising in Disguise?. Australasian Marketing Journal, 24-27. Available from: https://journals.sagepub.com/doi/10.1016/j.ausmj.2011.10.011\#articleCitationDownloadCo ntainer

Brewer, B., Andrzejewski, C., Vij, V., Muwakki, L., Lo, A. \& Evans, A. (2018). In-country assessments of baby food companies' compliance with the International Code of Marketing of Breast-milk Substitutes (Nigeria Report). Westat, Maryland.

Dewan Periklanan Indonesia. (2020). Etika Pariwara Indonesia Amandemen Tahun 2020. Dewan Periklanan Indonesia, Jakarta.

Food Safety Authority of Ireland. (2011). Scientific Recommendations for a National Infant Feeding Policy, $2^{\text {nd }}$ edition. Food Safety Authority of Ireland, Ireland.

Hernández-Cordero, S. \& et al. (2019). Violations of the International Code of Marketing of Breast-milk Substitutes in Mexico. Matern Child Nutrition, 15(1): e12682. Available from: https://pubmed.ncbi.nlm.nih.gov/30168899/

Howard, C., Howard, F., Lawrence, R., Andresen, E., DeBlieck, E. \& Weitzman, M. (2000). Office prenatal formula advertising and its effect on breast-feeding patterns. Obstet Gynecol., 95(2): 296-303. Available from: https://pubmed.ncbi.nlm.nih.gov/10674597/

Ikatan Dokter Anak Indonesia. (2013). Pengenalan Kode Pemasaran Pengganti ASI Internasional. Ikatan Dokter Anak Indonesia, Jakarta.

Kelly, C. \& Tumblety, J. (2019). Medical doctors and persuasion: Introduction. The Journal of The Historical Association, 104(359): 5-18. Available from: https://onlinelibrary.wiley.com/doi/abs/10.1111/1468-229X.12723

Kementerian Kesehatan Republik Indonesia. (2018). Pusat Data dan Informasi Kementerian Kesehatan Republik Indonesia, Menyusui Sebagai Dasar Kehidupan, Tema Pekan ASI Sedunia, 1-7 Agustus 2018. Kementerian Kesehatan Republik Indonesia, Jakarta.

Menteri Kesehatan Republik Indonesia. (2013). Peraturan Menteri Kesehatan Republik Indonesia No. 39 Tahun 2013 tentang Susu Formula Bayi dan Produk Bayi Lainnya. Kementerian Kesehatan Republik Indonesia, Jakarta.

Morgan, S., Waterston, T. \& Kerac, M. (2018). Infant formula advertising in medical journals: a cross-sectional study (and struggle to publish). Field Exchange 58, 29. Available from: www.ennonline.net/fex/58/infantformulaadvertising

Presiden Republik Indonesia. (1999). Peraturan Pemerintah Republik Indonesia No. 69 Tahun 1999 tentang Label dan Iklan Pangan. Presiden Republik Indonesia, Jakarta.

Presiden Republik Indonesia. (2012). Peraturan Pemerintah Republik Indonesia No. 33 Tahun 2012 tentang Pemberian Air Susu Ibu Eksklusif. Presiden Republik Indonesia, Jakarta. 
Pries, A. \& et al. (2016). Pervasive promotion of breastmilk substitutes in Phnom Penh, Cambodia, and high usage by mothers for infant and young child feeding. Matern Child Nutrition, p.11. Available from: https://pubmed.ncbi.nlm.nih.gov/27061955/

Tal, A. \& Wansink, B. (2016). Blinded with science: Trivial graphs and formulas increase ad persuasiveness and belief in product efficacy. Public Underst Sci, 25(1): 117-125. Available from: https://papers.ssrn.com/sol3/papers.cfm?abstract_id=2500965

UNICEF. (2020). Breastfeeding. UNICEF, New York. Available from: https://www.unicef.org/topics/breastfeeding

World Health Organization. (1981). International Code of Marketing of Breast-milk Subtitutes. World Health Organization, Geneva.

World Health Organization. (2020). Breastfeeding. World Health Organization, Geneva. Available from: https://www.who.int/health-topics/breastfeeding\#tab=tab_1 